\title{
Splenic lesions observed in 71 splenectomized dogs: a retrospective study
}

\author{
Lesões esplênicas observadas em 71 cães esplenectomizados: um \\ estudo retrospectivo
}

\author{
Elisângela Olegário da Silva ${ }^{1}$; Giovana Wingeter Di Santis ${ }^{2}$; \\ Selwyn Arlington Headley ${ }^{2}$; Ana Paula Frederico Rodrigues Loureiro Bracarence ${ }^{2 *}$
}

\begin{abstract}
The spleen of dogs is frequently affected by disorders that vary from local and systemic origin. The difficulty in associating clinical and gross findings contributes for the choice of total splenectomy as the main treatment, leading to an impairment of the immune and hematopoietic functions. The aim of this study was to evaluate the pathological findings in the spleen of splenectomized dogs during 2008 to 2014 at a Veterinary Teaching Hospital. From the 71 cases analyzed, 97,2\% (69/71) of the dogs were submitted to total splenectomy and 2,8\% (2/71) to partial splenectomy. In $45(63.4 \%)$ of these cases, the histopathological diagnosis was non-neoplastic alterations; only $36.6 \%$ (26/71) had a splenic neoplasia. The main non-neoplastic lesions observed were nodular hyperplasia $24.4 \%(11 / 45)$, infarction $22.3 \%(10 / 45)$, and hematoma $20 \%(9 / 45)$. The most frequent tumors were hemangiosarcoma $50 \%(13 / 26)$, histiocytic sarcoma $23 \%(6 / 26)$, and lymphoma $11.5 \%(3 / 26)$. The clinical methods used to diagnose splenic lesions were ultrasonography $88 \%(63 / 71)$, radiography $2.8 \%(2 / 71)$ and exploratory laparotomy $4.2 \%(3 / 71)$. In $4.2 \%(3 / 71)$ of these cases, the splenic changes were observed during therapeutic ovariohysterectomy. Results of the present study showed a prevalence of benign disorders in the spleen of splenectomized dogs associated with a high incidence of total splenectomy performed, indicating a difficulty in recognizing the different lesions that can affect the spleen by the veterinarian medical.
\end{abstract}

Key words: Dogs. Histopathological findings. Splenic disorders.

\section{Resumo}

O baço de cães é frequentemente afetado por alterações locais ou de origem sistêmica. A dificuldade em associar achados clínicos e macroscópicos contribuem para a escolha da esplenectomia total com principal tratamento, levando a um comprometimento das funções imune e hematopoiética. $\mathrm{O}$ principal objetivo deste estudo foi avaliar os achados patológicos no baço de cães esplenectomizados durante 2008 a 2014 em um Hospital Escola Veterinário. Dos 71 casos analisados, 97,2\% (69/71) dos cães foram submetidos à esplenectomia total e 2,8\% (2/71) à esplenectomia parcial. Em $45(63,4 \%)$ casos, o diagnóstico histopatológico foi de alterações não-neoplásicas; somente 36,6\% (26/71) tinham neoplasia esplênica. As principais alterações não-neoplásicas observadas foram hiperplasia nodular $24,4 \%(11 / 45)$, infarto $22,3 \%(10 / 45)$ e hematoma $20 \%(9 / 45)$. Os tumores mais frequentes foram

\footnotetext{
${ }^{1}$ Prof $^{a}$ M.e, Universidade do Oeste Paulista, UNOESTE, Presidente Prudente, Doutoranda do Programa de Pós-Graduação em Ciência Animal, Universidade Estadual de Londrina, UEL, Londrina, PR, Brasil. E-mail: elivet02@gmail.com

${ }^{2}$ Profs. Drs., Departamento de Medicina Veterinária Preventiva, UEL, Londrina, PR, Brasil. E-mail: giovanaws@uel.br; selwyn. headley@uel.br; ana.bracarense@pq.cnpq.br

* Author for correspondence
} 
hemangiossarcoma 50\% (13/26), sarcoma histiocítico 23\% (6/26) e linfoma esplênico 11,5\% (3/26). Os métodos clínicos utilizados para diagnóstico foram ultrassonografia $88 \%(63 / 71)$, radiografia 2,8\% (2/71) e laparatomia exploratória 4,2 (3/71). Em 4,2\% (3/71), as alterações esplênicas foram observadas durante ovariohisterectomia terapêutica. Os resultados do presente estudo evidenciam uma prevalência de alterações benignas no baço de cães esplenectomizados, associada com uma alta incidência de esplenectomias totais realizadas, indicam uma dificuldade dos médicos veterinários em reconhecer as diferentes lesões que podem acometer o baço.

Palavras-chave: Achados histopatológicos. Alterações esplênicas. Cães.

\section{Introduction}

The spleen is a hematopoietic organ that has several functions associated with the production of blood cells, hemoglobin iron metabolism, destruction of red blood cells and blood pool filtration, phagocytosis, and immune response (VALLI, 2007). This organ can be affected by trauma, torsion, and diseases associated with degenerative, circulatory, inflammatory, hyperplastic, and neoplastic (primary or metastatic) processes (VALLI, 2007; FRY; McGAVIN, 2012). Nodular or diffuse splenomegaly is the main macroscopic alteration diagnosed in veterinary practice by abdominal palpation, radiographs, ultrasound or exploratory laparotomy (FOSSUM, 2007).

Diseases and disorders associated with splenomegaly are classified as (i) uniform splenomegaly with a bloody consistency (bloody spleen), (ii) uniform splenomegaly with a firm consistency (meaty spleen), (iii) splenic nodule with a bloody consistency, and (iv) splenic nodule with a firm consistency (FRY; McGAVIN, 2012). The most common causes of uniform splenomegaly with bloody consistency are congestion, acute hyperemia, and acute hemolytic anemia, whereas bloody nodules are associated with hematomas, incompletely contracted areas, acute infarcts, and vascular neoplasms. Uniform splenomegaly with a firm consistency is related to extensive phagocytosis, infiltration of inflammatory cells, extramedullary hematopoiesis, diffuse primary or metastatic tumours. The main causes of the formation of firm nodules are nodular hyperplasia, fibrohistiocytic proliferation, primary and metastatic neoplasms, granulomas, and abscess (VALLI, 2007; FRY; McGAVIN, 2012).

The specific cause of splenomegaly should be established, considering that splenic enlargement is usually a secondary manifestation of some other clinical problem. An adequate anamnesis, complete clinical examination, ultrasound and radiographic examinations are essential for the diagnosis of splenic disorders (NYLAND et al., 2002). Ultrasound-guided biopsy by aspirate or tissue-core can be useful to diagnosis spleen disorders (NYLAND et al., 2002; MACWILLIAMS, 2008). However, in some cases where severe thrombocytopenia or hemangiosarcoma are suspected, these procedures may cause complications (MACWILLIAMS, 2008). The definitive diagnosis of spleen disorders should be obtained through histopathological examination (JACOBS et al., 2002; VALLI, 2007).

Partial splenectomy is recommended if possible, as treatment of choice for spleen disorders (FOSSUM, 2007). However, due to the lack of knowledge of alterations that can affect the spleen and the difficulty to differentiate between benign and malignant lesions at the gross examination during laparotomy, total splenectomy is frequently performed as a routine veterinary clinical surgical intervention.

Several retrospective studies (SPANGLER; CULBERSTON, 1992; DAY et al., 1885; BANDINELLI et al., 2011) that have evaluated 
the disorders in spleen of dogs with emphasis on histopathological diagnosis, but no study that discussed the relationship between the image analysis and gross findings was located. This retrospective study aimed to characterize splenic histopathological findings associate these with clinical, image and gross features of dogs submitted splenectomy in a Veterinary Teaching Hospital during the period of 2008-2014.

\section{Material and Methods}

A retrospective survey of all histopathological splenic diagnosis from splenectomized dogs attended at the Veterinary Teaching Hospital/ Universidade Estadual de Londrina, Brazil during January 2008 to December 2014 was done. Data relative to breed, age, sex, clinical signs, image exams and histopathological diagnosis were reviewed and tabulated. Statistical analysis of proportional data was used. In this study, cases of splenic trauma and rupture were not included. The splenic samples were fixed in 10\% neutral buffered formalin, dehydrated in alcohols and embedded in paraffin. Sections of $4 \mu \mathrm{m}$ were stained with hematoxylin-eosin (H\&E) for histopathological evaluation.

\section{Results and Discussion}

During the period evaluated, 71 dogs were attended at the Veterinary Teaching Hospital for splenic surgery; 97\% (69/71) of these were submitted for total splenectomy and 3\% (2/71) for partial splenectomy. In 45 (63.4\%) of these cases, the histopathological diagnoses were non-neoplastic alterations, whereas neoplasia contributed to 26 (36.6\%) cases (Tables 1 and 2). A greater frequency of splenic non-neoplastic alterations was also reported by Christensen et al. (2009). On the other hand, other studies described neoplasms as the most common splenic disorder (DAY et al., 1995; BANDINELLI et al., 2011).

Table 1. Neoplastic and non-neoplastic histopathological diagnoses from the spleens of splenectomized dogs (2008 to 2014).

\begin{tabular}{|c|c|c|c|c|c|}
\hline Diagnosis & $\begin{array}{c}\text { Number of cases } \\
\text { (\%/total non-neoplastic lesions) }\end{array}$ & $\begin{array}{c}\text { \% of total } \\
\text { splenic lesions }\end{array}$ & $\begin{array}{c}\text { Mean age } \\
\text { (years) }\end{array}$ & $\begin{array}{l}\mathrm{Se} \\
\mathrm{M}\end{array}$ & $\mathbf{F}$ \\
\hline \multicolumn{6}{|l|}{ Non-neoplastic } \\
\hline Abscess & $3(6.7 \%)$ & $4.2 \%$ & $7.6(4$ to 12$)$ & 2 & 1 \\
\hline Congestion & $5(11.1 \%)$ & $7 \%$ & $8.6(6$ to 11$)$ & 3 & 2 \\
\hline $\begin{array}{l}\text { Extramedullary } \\
\text { hematopoiesis }\end{array}$ & $5(11.1 \%)$ & $7 \%$ & $8.2(6$ to 9$)$ & 0 & 5 \\
\hline Infarction & $10(22.3 \%)$ & $14 \%$ & $10(6$ to 14$)$ & 5 & 5 \\
\hline Hematoma & $9(20 \%)$ & $12.6 \%$ & $9.4(2$ to 15$)$ & 3 & 6 \\
\hline Hemorrhage & $2(4.4 \%)$ & $2.8 \%$ & $6(5$ to 7$)$ & 0 & 2 \\
\hline Nodular hyperplasia & $11(24.4 \%)$ & $15.8 \%$ & 9.5 (4 to 16$)$ & 3 & 8 \\
\hline Total & $45(100 \%)$ & $63.4 \%$ & $8.4(2$ to 15$)$ & 16 & 9 \\
\hline Neoplastic & $\% /$ total neoplastic lesions & & & & \\
\hline Hemangioma & $1(3.9 \%)$ & $1.4 \%$ & $12(12)$ & 0 & 1 \\
\hline Hemangiosarcoma & $13(50 \%)$ & $18.3 \%$ & $10.6(7$ to 14$)$ & 6 & 7 \\
\hline Histiocytic Sarcoma & $6(23 \%)$ & $8.4 \%$ & 10.8 (6 to 14$)$ & 3 & 3 \\
\hline Lymphoma & $3(11.5 \%)$ & $4.2 \%$ & $9(4$ to 14$)$ & 1 & 2 \\
\hline Metastasis & $2(7.7 \%)$ & $2.8 \%$ & $13(10$ to 16$)$ & 0 & 2 \\
\hline Myelolipoma & $1(3.9 \%)$ & $1.4 \%$ & $12(12)$ & 0 & 1 \\
\hline Total & $26(100 \%)$ & $36.6 \%$ & $11.2(4$ to 16$)$ & 10 & 16 \\
\hline
\end{tabular}


Nodular splenic disease was observed in $83.1 \%$ (59/71) of the splenectomized dogs; $67.8 \%$ (40/59) of these were non-neoplastic and 32.2\% (19/59) neoplastic disorders. Uniform splenomegaly was observed in $16.9 \%(12 / 71)$ of all cases; from these cases, 12 were non-neoplastic changes and one a neoplasm (Table 1). The elevated prevalence of non-neoplastic nodular disorders suggest that total splenectomy should be replaced by partial splenectomy in dogs, since total splenectomy increases the susceptibility to blood-borne infections, septicemia, and hemoparasites (FRY; McGAVIN, 2012). Moreover, most of the dogs with uniform splenomegaly had non-neoplastic alterations indicating that the splenectomy procedure used was unnecessary.

Table 2. Summary of neoplastic and non-neoplastic lesions, clinical methods for identification of splenic changes and gross examination in splenectomized dogs (2008 to 2014).

\begin{tabular}{|c|c|c|c|c|c|c|c|c|c|}
\hline \multirow{2}{*}{ Histopathological Diagnosis } & \multirow{2}{*}{ USG } & \multirow{2}{*}{$\mathbf{R X}$} & \multirow{2}{*}{$\mathbf{E L}$} & \multirow{2}{*}{ OSH } & \multirow{2}{*}{ US } & \multirow{2}{*}{ NS } & \multicolumn{3}{|c|}{ Gross Examination } \\
\hline & & & & & & & US* & NS\# & NC \\
\hline Abscess & 3 & 0 & 0 & 0 & 0 & 3 & 0 & 3 & 0 \\
\hline Congestion & 5 & 0 & 0 & 0 & 2 & 3 & 1 & 0 & 4 \\
\hline Extramedullary hematopoiesis & 5 & 0 & 0 & 0 & 0 & 5 & 0 & 3 & 2 \\
\hline Hemangioma & 1 & 0 & 0 & 0 & 0 & 1 & 0 & 1 & 0 \\
\hline Hemangiosarcoma & 12 & 1 & 0 & 0 & 0 & 13 & 0 & 13 & 0 \\
\hline Hematoma & 8 & 0 & 0 & 1 & 1 & 8 & 0 & 6 & 3 \\
\hline Hemorrhage & 1 & 0 & 1 & 0 & 1 & 1 & 1 & 1 & 0 \\
\hline Histiocytic Sarcoma & 6 & 0 & 0 & 0 & 1 & 5 & 1 & 5 & 0 \\
\hline Infarction & 8 & 1 & 1 & 0 & 3 & 7 & 2 & 5 & 3 \\
\hline Lymphoma & 2 & 0 & 1 & 0 & 1 & 2 & 1 & 2 & 0 \\
\hline Metastasis & 1 & 0 & 0 & 1 & 0 & 2 & 0 & 2 & 0 \\
\hline Myelolipoma & 1 & 0 & 0 & 0 & 0 & 1 & 0 & 1 & 0 \\
\hline Nodular hyperplasia & 10 & 0 & 0 & 1 & 3 & 8 & 2 & 6 & 3 \\
\hline Total & 63 & 2 & 3 & 3 & 12 & 59 & 8 & 48 & 15 \\
\hline
\end{tabular}

USG: ultrasonography examination; RX: radiography examination; EL: exploratory laparotomy;

OSH: ovariosalpingohysterectomy; US: uniform splenomegaly; NS: nodular splenomegaly.

US*: uniform splenomegaly confirmed by gross examination; NS\#: nodular splenomegaly

confirmed by gross examination; NC: no gross change observed.

Non-neoplastic findings observed in the present study included alterations of circulatory $68.9 \%(31 / 45)$, hyperplasic $24.4 \%$ (11/45), and infectious $6.7 \%$ (3/45) origin. The non-neoplastic changes observed were infarction, extramedullary hematopoiesis, congestion, hemorrhage, hematoma, nodular lymphoid hyperplasia, and abscess (Figure 1). The most common non-neoplastic changes observed were nodular hyperplasia 24.4\% (11/45) followed by infarction $22.3 \%$ (10/45) and hematoma $20 \%(9 / 45)$. These disorders were also the main benign alterations observed in canine spleen from previous studies (SPANGLER; CULBERSTON, 1992; DAY et al., 1995; BANDINELLI et al., 2011). The mean age of the dogs was 8.4 years and females (29/45) were overrepresented. The number, percentage, age, and sex distribution of the nonneoplastic lesions are presented in Table 1.

Nodular hyperplasia is a common lesion observed in older dogs and frequently is an incidental finding during ultrasonography evaluation and exploratory laparotomy. This lesion is composed of hyperplastic 
lymphoid cells or large concentrations of erythrocytes, myeloid, lymphoid and megakaryocytic cells. These lesions are usually exophytic, measuring $2 \mathrm{~cm}$ or more, presenting intermixed areas of red and white on cross-section (FRY; McGAVIN, 2012). Infarction and hematoma are common circulatory disorders. The former, normally occurs in the subcapsular area as result of vein or arterial thrombosis and initially present hemorrhagic appearance that posteriorly becomes gray-white to form a scar. The latter is secondary to bleeding into the red pulp due to trauma, hematological changes or rupture of vascular neoplasms and usually is present as a solitary mass or nodule of varying size (VALLI, 2007; FRY; McGAVIN, 2012). In the cases diagnosed as hematoma, five to seven sections of the spleen were done and no primary lesion that could have triggered the hematoma, such as nodular hyperplasia or hemangiossarcoma, was observed. Therefore, nodular hyperplasia, infarction, and hematoma of the spleen should be included in the differential diagnosis of dogs with splenic nodular formations.

Figure 1. Splenic lesions observed in splenectomized dogs. A-B-Chronic Hematoma; reddish and soft welldelimited mass. C-D-Nodular hyperplasia; firm nodules well-delimited with reddish and whitish areas (arrows). E-F- Histiocytic Sarcoma; poorly-delimited multinodular mass with firm consistency, reddish and whitish areas. G-H- Hemangiosarcoma; poorly-delimited ulcerated mass with smooth consistency and red darkened color.

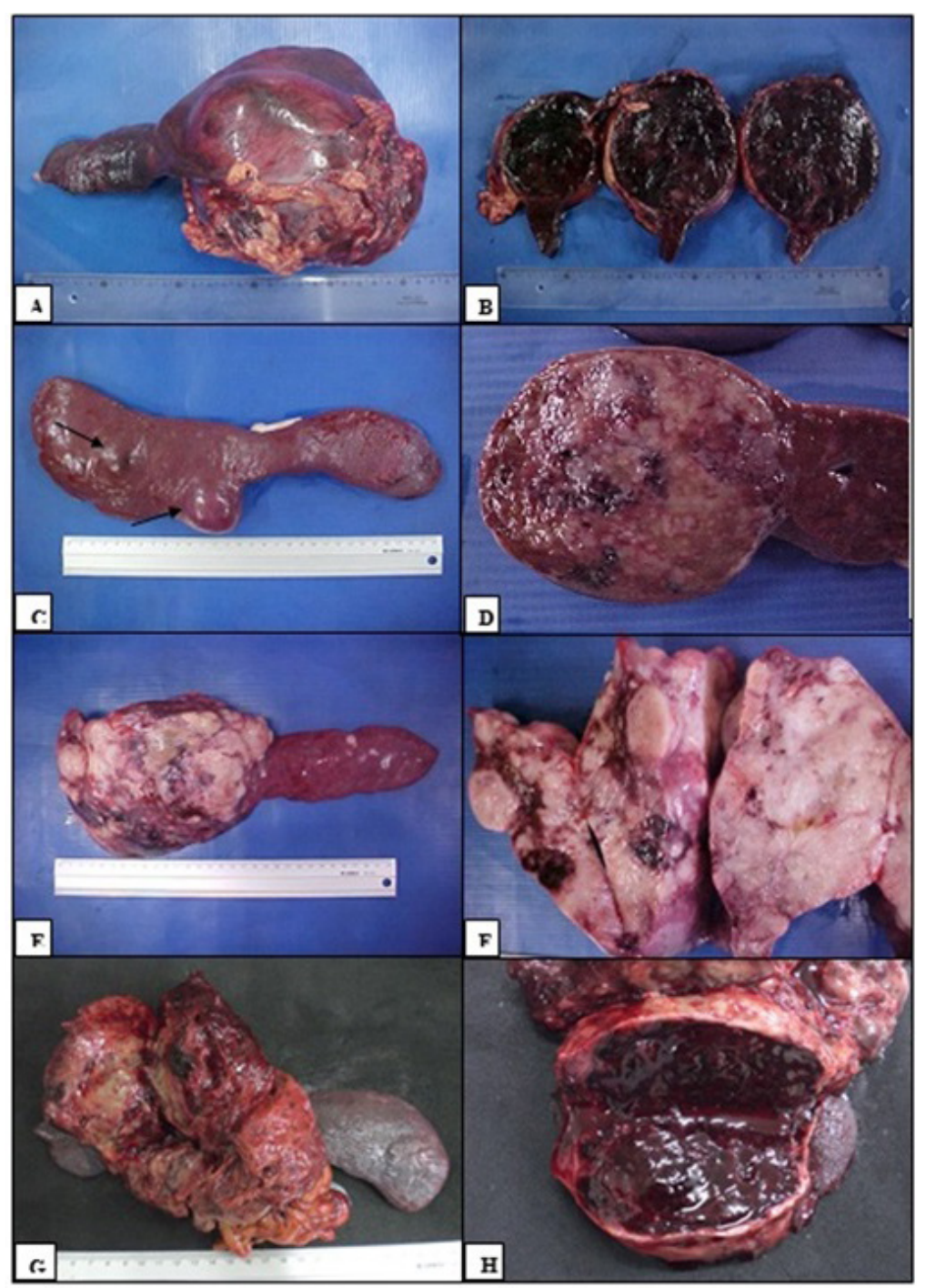


Splenic neoplasia was observed in 26 dogs; 24 $(92.2 \%)$ of these were malignant tumors with only two $(7.8 \%)$ benign neoplasms. The mean age of the affected animals was 11.2 years and females were over represented (15/26). The neoplasms observed in this study were hemangiosarcoma, histiocytic sarcoma, lymphoma, metastasis of mammary carcinoma, myelolipoma, and hemangioma (Figure 1). The most frequent tumors diagnosed during this study were hemangiosarcoma 50\% (13/26), histiocytic sarcoma $23 \%(6 / 26)$ and lymphoma $11.5 \%(3 / 26)$, with no sex or breed predisposition. Similar results were previously reported with a higher incidence of hemangiosarcoma followed by other sarcomas such as fibrossarcoma, anaplastic sarcoma and leiomyosarcoma (DAY et al., 1995; BANDINELLI et al., 2011). The number, percentage, age, and sex distribution of the cases are presented at Table 1. Primary splenic tumors can arise from normal cell populations of the spleen, including hematopoietic components, such as lymphocytes, mast cells, macrophages and stroma cells, such as fibroblasts, smooth muscle cells and endothelium (FRY; McGAVIN, 2012). The most common splenic tumors observed in dogs are hemangiosarcoma and lymphoma (THAMM, 2007; VAIL; YOUNG, 2007).

Hemangiosarcoma is an aggressive tumor with elevated incidence of metastasis that can lead to anemia, thrombocytopenia, alterations in the coagulation cascade, disseminated intravascular coagulation, ascites, hemoperitoneum, and hypovolemic shock due to tumor rupture (THAMM, 2007). Dogs with lymphoma showed spleen involvement in $60 \%$ of the cases (JACOBS et al., 2002); however, in this and other studies (DAY et al., 1995; BANDINELLI et al., 2011) a lower incidence was observed in splenectomized dogs. This difference is probably related to the multicentric lymphoma presentation where the treatment of choice is not splenectomy (FOSSUM, 2007; THAMM, 2007). In the cases of lymphoma in the present study, only splenic involvement was observed.
In $39.4 \%(28 / 71)$ of the cases observed during this study, dogs had a previous history of a malignant tumor, however in only two of these the presence of splenic metastasis was observed. This lower incidence of splenic metastasis can be related to an efficient macrophage activity preventing the colonization of tumorous cells (VALLI, 2007; FRY; McGAVIN, 2012). Therefore, metastatic neoplastic disease of the spleen is uncommon (DAY et al., 1995; BANDINELLI et al., 2011), and a previous history of malignant tumor should not be the main criterion for performing a total splenectomy in dogs before a complete systemic investigation is done.

Pure breed dogs represented 76\% (54/71) of all cases evaluated during the period, with mixed breeds being $24 \%$ (17/71) of all cases. The most affected breeds were the Boxer 11.2\% (8/71), English Cocker Spaniel 11.2\% (8/71), Poodle 11.2\% (8/71), Pit Bull 7\% (5/71), and Rottweiller 5.6\% (4/71). Similar results were previously described (BANDINELLI et al., 2011). The breed prevalence observed likely reflected the canine population attended at the local Veterinary Hospital. Although there was no breed predisposition to any specific splenic disorder, medium and large breeds were most affected by splenic neoplastic and non-neoplastic lesions; similar results were described (BROWN et al., 1985; DAY et al., 1995; BANDINELLI et al., 2011).

Clinical signs of splenic disorders are nonspecific and include weakness, anorexia, and abdominal distension. Animals with vascular tumors or hematomas can present hemoperitoneum and anemia due to rupture of the nodule/mass (FOSSUM, 2007; THAMM, 2007). In the present study, the main clinical signs were anemia 28\% (20/71) and ascites $7 \%$ (5/71). These clinical manifestations were more frequent in dogs with hemangiosarcoma, where anemia occurred in $77 \%(10 / 13)$ of these and ascites in $23 \%(3 / 13)$. The high incidence of anemia probably is related to intratumoral keeping of blood and reduction of circulatory blood volume. 
In this study, the clinical methods used to diagnose splenic changes were ultrasonography $88 \%(63 / 71)$, radiography $2.8 \%(2 / 71)$, exploratory laparotomy $4.2 \%(3 / 71)$, and therapeutic ovariohysterectomy $4.2 \%(3 / 71)$. Splenic alterations were confirmed during gross examination in $78.9 \%(56 / 71)$ of these cases. In $21.1 \%(15 / 71)$ of the cases, no macroscopic alterations were observed. From these, four and 11 cases had a previous ultrasonographic diagnosis of uniform splenomegaly and nodular splenomegaly, respectively. Data relative to the diagnosis method used, gross alterations and histopathological diagnosis are given in Table 2.

Ultrasonography is the most common examination to detect splenic alterations (NYLAND, 2002). Despite the characteristic of this method as non-invasive and effective in the evaluation of splenic parenchyma, the ultrasound appearance of focal and extensive lesions usually does not allow a definitive diagnosis of benign or malignant lesion (NYLAND, 2002; FOSSUM, 2007). Therefore, ultrasonographic findings must be correlated with the history, clinical signs, and laboratory examinations to establish a differential diagnosis. The ultrasound-guided biopsy by aspirate or tissue-core is very helpful to determine uniform and nodular splenomegaly (O'KEEFE; COUTO, 1987; NYLAND, 2002; THRALL, 2007; CHRISTENSEN et al., 2009). No complications have been reported with splenic aspirates or tissue-core exam if the coagulation parameters are normal (NYLAND, 2002). A contraindication to splenic aspiration is the presence of splenic masses containing fluid-filled cystic structures (e.g. hemangiosarcoma) because rupture or implant of tumoral cells in the peritoneum may occur (THRALL, 2007). In this study, no aspirate or tissue-core biopsy was performed. Probably, the use of these exams in the hospital routine will improve previous diagnosis of splenic lesions, avoiding total splenectomy in most cases.

\section{Conclusion}

The results of the present study showed a predominance of benign disorders in the spleen of splenectomized dogs. The high incidence of total splenectomy performed indicates a difficulty in recognizing the different alterations affecting the spleen. Therefore, it is recommended that veterinarians should conduct a full correlation within the history, clinical signs, image complementary evaluations and the implantation of ultrasoundguided aspirates or tissue core to avoid unnecessary total splenectomies, preserving the immune and hematopoietic systems before opting for surgical therapy.

\section{References}

BANDINELLI, M. B.; PAVARINI, S. P.; OLIVEIRA, E. C.; GOMES, D. C.; CRUZ, C. E. F.; DRIEMEIER, D. Estudo retrospectivo de lesões em baços de cães esplenectomizados: 179 casos. Pesquisa Veterinária Brasileira, Seropédica, v. 31, n. 8, p. 697-701, 2011.

BROWN, N. O.; PATNAIK, A. K.; MACEWEN, E. G. Canine hemangiosarcoma: retrospective analysis of 104 cases. Journal of American Veterinary Medical Association, Illinois, v. 186, n. 1, p. 56-58, 1985.

CHRISTENSEN, N. I.; CANFIELD, P.; MARTIN, P.; KROCKENBERGER, M.; SPIELMAN, D.; BOSWARD, K. Cytopathological and histopathological diagnosis of canine splenic disorders. Australian Veterinary Journal, Victoria, v. 87, n. 5, p. 175-181, 2009.

DAY, M. J.; LUCKE, V. M.; PEARSON, H. A review of pathological diagnoses made from 87 canine splenic biopsies. Journal of Small Animal Practice, Oxford, v. 36, n. 10, p. 426-433, 1995.

FOSSUM, T. W. Surgery of the hemolymphatic system. In: $\quad$. Small animal surgery. $3^{\text {th }} \mathrm{ed}$. St Louis: Mosby Elsevier, 2007. p. 617-634.

FRY, M. M.; McGAVIN, M. D. Bone marrow, blood cells, and the lymphatic system. In: ZACHARY, J. F.; McGAVIN, M. D. Pathologic basis of veterinary disease. $5^{\text {th }}$ ed. St. Louis: Elsevier, 2007. p. 698-770.

JACOBS, R. M.; MESSICK, J. B.; VALLI, V. E. Splenic lymphoid hyperplasia and nonlymphoid splenic diseases. In: MEUTEN, D. J. Tumors in domestic animals. $4^{\text {th }} \mathrm{ed}$. Iowa: Iowa State Press, 2002. p. 194-196. 
MACWILLIAMS, P. S. The spleen. In: COWELL, R. L.; TYLER, R. D.; MEINKOTH, J. H.; DeNICOLA, D. B. Diagnostic cytology and hematology of the dog and cat. $3^{\text {th }}$ ed. St. Louis: Mosby Elsevier, 2008. p. 330-337.

NYLAND, T. G.; MATTOON, J. S.; HERRGESELL, E. J.; WISNER, E. R. Ultrasound-guided biopsy. In: NYLAND, T. G.; MATTOON, J. S. Small animal diagnostic ultrasound. $2^{\text {th }}$ ed. Philadelphia: W. B. Saunders Company, 2002. p. 41-42.

O'KEEFE, D. A.; COUTO, C. G. Fine-needle aspiration of the spleen as an aid in the diagnosis of splenomegaly. Journal of Veterinary Internal Medicine, Philadelphia, v. 1, n. 3, p. 102-109, 1987.

SPANGLER, W. L.; CULBERSTON, M. R. Prevalence, type, and importance of splenic diseases in dog: 1,480 cases (1985-1989). Journal of American Veterinary Medical Association, Illinois, v. 200, n. 6, p. 829-834, 1992.
THAMM, D. H. Miscellaneous tumors. In: WITHROW, S. J.; VAIL, D. M. Withrow \& MacEwen's small animal clinical oncology. $4^{\text {th }}$ ed. St. Louis: Saunders Elsevier, 2007. p. 789-795.

THRALL, M. A. Diagnostic cytology in clinical oncology. In: WITHROW, S. J.; VAIL, D. M. Withrow \& MacEwen's small animal clinical oncology. $4^{\text {th }}$ ed. St. Louis: Saunders Elsevier, 2007. p. 112-133.

VAIL, D. M.; YOUNG, K. M. Hematopoietic tumors. In: WITHROW, S. J.; VAIL, D. M. Withrow \& MacEwen's small animal clinical oncology. $4^{\text {th }}$ ed. St. Louis: Saunders Elsevier, 2007. p. 699-784.

VALLI, V. E. O. Hematopoietic system. In: MAXIE, M. G. Jubb, Kennedy and Palmer's - pathology of domestic animals. $5^{\text {th }}$ ed. Philadelphia: Elsevier Saunders, 2007. p. 284-290. 